\title{
Gamle steinsamlingar; gravminne, ryddingsrøyser - eller kva?
}

\author{
EVEN BJØRDAL
}

Bjørdal, E. 2020. Old piles of stones; burial markers, clearance cairns - or what? AmS-Varia 61, 43-59, Stavanger, ISSN 0332-6306, ISBN 978-82-7760-187-8

\begin{abstract}
This article discusses how to better unlock the information potential of unremarkable, though complex, prehistoric stone-built structures, by integrating the past 30 years worth of Nordic archaeological research results into aspects of the Norwegian Cultural Heritage Management processes. Traditionally, it has been rather commonplace to interpret such manmade collections of rocks as remains of either clearance of fields for agricultural purposes or as containers for burials, but this dichotomy should now be regarded as an oversimplification. The site of Orstad in the county of Rogaland, SW Norway, excavated in 2014, serves as a case study. This paper demonstrates how difficult it can be to put updated theories and methods into proper use in the field. Since these new research results call for changes in the approach to the subject were not sufficiently considered in the planning process, neither time nor budget allowed for an adequate examination of the individual structures and their context. This is likely to cause information loss, which creates challenges for both the excavation and post-excavation phases of an archaeological investigation. This paper stresses the need to update and improve how excavations of such sites are handled within Norwegian cultural heritage management. By applying new approaches, such localities can yield more information about the past than previously assumed.
\end{abstract}

Even Bjørdal, Museum of Archaeology, University of Stavanger, N-4036 STAVANGER, NORWAY.

E-mail: even.bjordal@uis.no

Keywords: cultural heritage management, case study, cairns, Bronze Age, Iron Age

\section{Innleiing}

Å skilje mellom førhistoriske spor etter høvesvis religiøse og/eller kulturelle handlingar og det daglegdagse, praktiske livet, er utbreidd i samband med sortering og rangering av kulturminner. Dikotomien kan til dømes nyttast ved argumentasjon for eller imot vern av ein lokalitet i eit pressområde, eller ved utval av kva slag anlegg som bør samanliknast i eit forskingsarbeid. Det har i Noreg vore vanleg, særleg innan forvaltingsarkeologien, å tolke førreformatoriske steinkonstruksjonar, ofte kalla «røyser», til ein av to hovudkategoriar. Dei er anten gravleggingsstad og minnesmerke over avlidne menneske («gravrøyser»), eller spor etter tilrettelegging av landskapet for betre å kunne bu, dyrke jorda eller drive med beitedyr («ryddingsrøyser»). Erfaringar frå både arkeologiske enkeltundersøkingar, og meir samanliknande forsking på tematikken «røyser», tyder på at ei slik todeling er meir lett enn rett.

Hovudføremålet med denne artikkelen er å gje eit tilskot til fagdebatten om korleis arkeologar og andre innan kulturminnevernet bør forhalde seg til steinsamlingane i gråsona, det vil seie objekta som verken framstår som klare, steinbygde gravminner eller som ryddingsrøyser - samanraska dungar av steinar frå rydda flater.

Artikkelen fokuserer på utfordringar knytt til fasane planlegging, utgraving og etterarbeid i samband med forvaltingsundersøkingar av kontekstar som vert kalla røys. Sider ved feltarkeologi, faglege omgrep og tradisjonelle tolkingar vert diskuterte og problematiserte, med utgangspunkt i materiale frå ei slik representativ nyleg utført utgraving i Rogaland. 


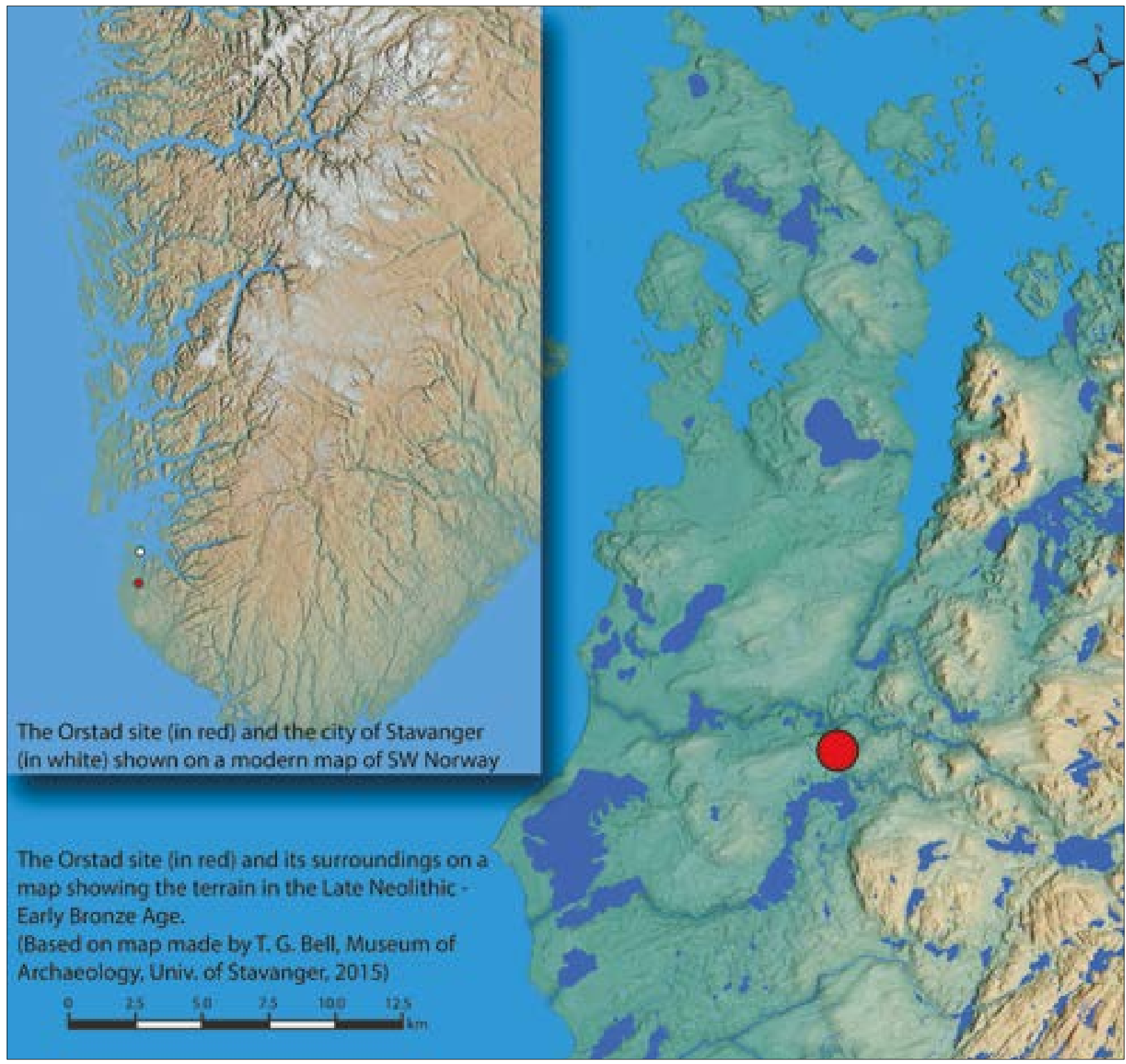

Fig. I. Oversynskart som viser lokaliseringa av Orstad i Rogaland, SV-Norge. Basert på kart laget av Theo G. Bell, 2015.

Fig. I. Map showing the Orstad site in Rogaland, SW Norway. Based on map originally made by Theo G. Bell 2015.

\section{Undersøkinga på Orstad}

Innleiande presentasjon av lokalitet og

undersøkingsresultat

Det er funne fleire spor etter førhistorisk aktivitet på Orstad i Klepp kommune, frå høvesvis jordbruk, busetnad og røyser. Dei fleste vart funne ved tidlegare undersøkingar, anten på den øvre delen av Orstadhøgdedraget eller på sørsida av dette (jf. Hemdorff, 1987; Hemdorff \& Sageidet, 1997). Dei faste kulturminna var hovudsakleg registrerte som anten graveller ryddingsrøyser, både enkeltståande og større felt av slike. I 2014 utførte Arkeologisk museum, UiS ei forvaltingsundersøking av lokalitetane Id. 157479
«Felt 1») og 157480 («Felt 2») på Orstad (jf. Fig. 1, 2, 3, 4, og Bjørdal \& Rødsdalen, 2017). Disse lokalitetane framstod som relativt perifere, der dei grensa opp mot kvarandre i eit beitemarklandskap prega av høvesvis slake skråningar, små flater og ein del fuktige søkk.

Det blei ved utgravinga påvist spor etter til saman 25 førreformatoriske anlegg, majoriteten av desse låg på og ved ein låg kolle på Felt 1, om lag 65 moh. (sjå Fig. 3 og 4). Anleggsspora var røyser og andre former for intensjonelle steinsamlingar, eld-/kokegroper og meir uavklarte groper. Kollen er tolka som eit område med restar etter både tidleg jordbruk (truleg rydda for beitemark) og kultisk aktivitet i delar av førhistoria. 


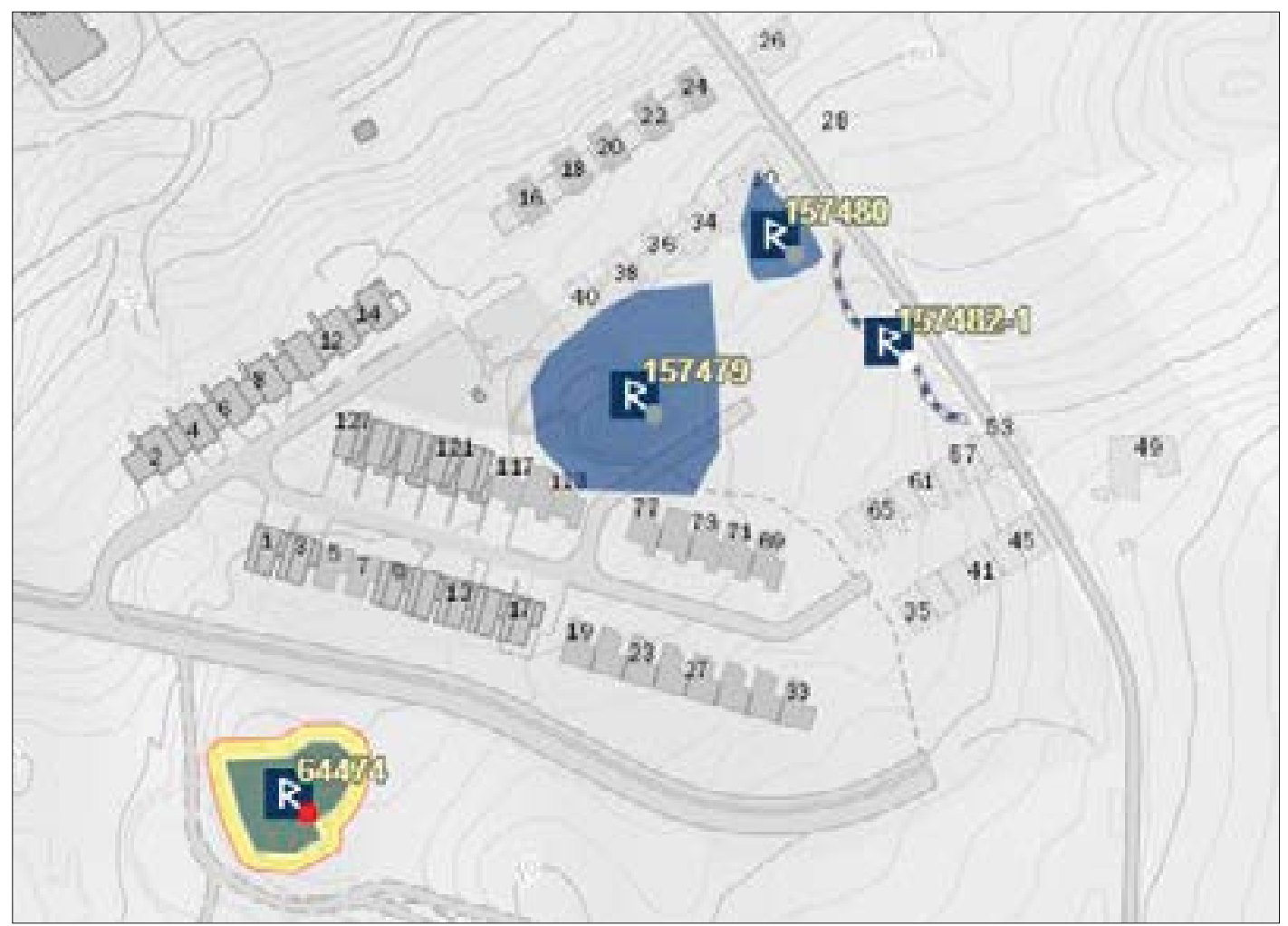

Fig. 2. Id. 157479 og 157480 med kulturminnekontekst på Orstad. Fra Askeladden.

Fig. 2. The two localities constituting the Orstad site (Id. 157479 and 157480) and their surroundings. Map from the Askeladden database.

Tabell I. Tabell over ${ }^{14} \mathrm{C}$-dateringar frå Orstadundersøkinga i 20।4. Tabell: Even A. A. Bjørdal. Table I. Table showing ${ }^{14} \mathrm{C}$-datings from the 2014 Orstad excavation. Table: Even A. A. Bjørdal.

\begin{tabular}{|c|c|c|c|c|c|}
\hline $\begin{array}{l}\text { Prøvenummerl } \\
\text { Sample no }\end{array}$ & $\begin{array}{l}\text { Strukturl } \\
\text { Structure }\end{array}$ & $\begin{array}{l}\text { Materialel } \\
\text { Material }\end{array}$ & $\begin{array}{l}\text { År BPI } \\
\text { Years BP }\end{array}$ & $+/-$ & $\begin{array}{l}\text { Kalibrert alder/BP } \\
\text { Calibrated years BC/AD }\end{array}$ \\
\hline & & & & & (Beta, INTCAL I3) \\
\hline Beta-399230 & Anlegg $2 /$ Structure 2 & Hasselnøtskal/Hazel nut shell & 2380 & 30 & 535-395 f. Kr. /BC \\
\hline Beta-407422 & Anlegg $7 /$ Structure 7 & $\begin{array}{l}\text { Trekol (lauvtre; ikkje eik) } \\
\text { Charcoal (deciduous; not oak) }\end{array}$ & 6200 & 30 & $5225-5055$ f. Kr. $/ B C$ \\
\hline Beta-407423 & Anlegg 14/Structure 14 & Hasselnøtskal/Hazel nut shell & 2500 & 30 & $785-535 / 525-520$ f. Kr. $/ B C$ \\
\hline Beta-399237 & $\begin{array}{l}\text { Eld-/ Kokegrop } 1562 \\
\text { Fire pit } 1562\end{array}$ & Trekol (hassel/or)/Charcoal (hazel/alder) & 2460 & 30 & $765-410$ f. Kr. /BC \\
\hline Beta-39923I & Anlegg $9 /$ Structure 9 & Hasselnøtskal/Hazel nut shell & 1790 & 30 & I35-265/275-330 e. Kr. /AD \\
\hline Beta-399232 & $\begin{array}{l}\text { Anlegg 13, lag } 2 \\
\text { Structure 13, layer } 2\end{array}$ & Hasselnøtskal/Hazel nut shell & 2170 & 30 & $\begin{array}{l}355-275 / 255-165 / \\
125-\mid 20 \text { f. Kr. /BC }\end{array}$ \\
\hline Beta-399238 & $\begin{array}{l}\text { Anlegg } 13 \text {, lag I } \\
\text { Structure } 13 \text {, layer I }\end{array}$ & Trekol (Hassel/or)/Charcoal (hazel/alder) & 3520 & 30 & $1930-1750$ f. Kr. /BC \\
\hline Beta-399233 & $\begin{array}{l}\text { Eld-/ Kokegrop } 1317 \\
\text { Fire pit } 1317\end{array}$ & Hasselnøtskal/Hazel nut shell & 2630 & 30 & $825-790$ f. Kr. /BC \\
\hline Beta-399234 & Anlegg 12/Structure 12 & Hasselnøtskal/Hazel nut shell & 2900 & 30 & $\begin{array}{l}1205-1140 / \\
1130-1005 \text { f. Kr. /BC }\end{array}$ \\
\hline Beta-399239 & Anlegg II/Structure II & Trekol (bjørk)/Charcoal (birch) & 3050 & 30 & $1405-1220$ f. Kr./BC \\
\hline Beta-399235 & Anlegg 10/Structure 10 & Hasselnøtskal/Hazel nut shell & 2450 & 30 & $760-410$ f. Kr./BC \\
\hline Beta-399236 & $\begin{array}{l}\text { Eld-/ Kokegrop } 1625 \\
\text { Fire pit } 1625\end{array}$ & Hasselnøtskal/Hazel nut shell & 3070 & 30 & $\begin{array}{l}1415-1260 / \\
1240-1235 \text { f. Kr. } / B C\end{array}$ \\
\hline Beta-407424 & Anlegg 14/Structure I4 & $\begin{array}{l}\text { Brent bein (Kremert menneskebein: materiale } \\
\text { plukka frå } 2014 / 12-10 \text { og gjeve eige } \mathrm{nr} .63 \text { ) } \\
\text { Cremated human bone: given separate sample } \\
\text { no }-63 \text {, but orig. from sample } 20 / 4 / / 2-10\end{array}$ & 1780 & 30 & I35-335 e. Kr. /AD \\
\hline
\end{tabular}


Fig. 3. Oversyn over steinkonstruksjonar på Id. 157479. Foto: AM, UiS.

Fig. 3. Overview of stone built structures within locality Id. 157479. Photo: AM, UiS.

Fig. 4. Oversyn over steinkonstruksjonar på Id. 157480. Foto: AM, UiS.

Fig. 4. Overview of stone built structures within locality Id. 157480. Photo: AM, UiS.
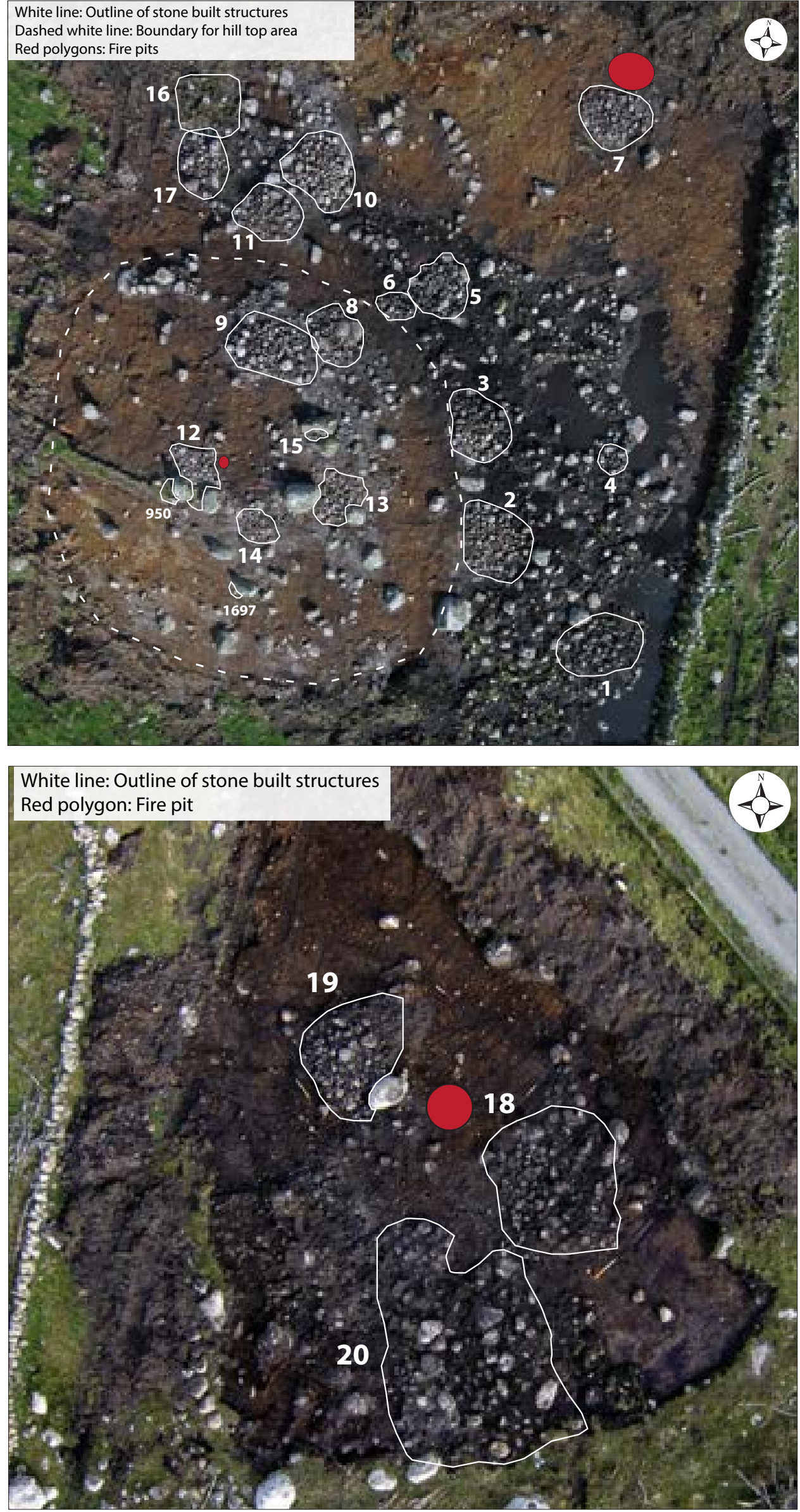
Majoriteten av ${ }^{14} \mathrm{C}$-dateringar, utført på delvis forkola materiale funne i desse anlegga, viser til aktivitet frå bronsealder og førromersk tid (sjå Tabell 1). Dei eldste funna frå undersøkinga er derimot avfall og reiskapar av flint, som etter alt å døme stammar frå fleire, kortvarige opphald på kollen i løpet av steinalderen. Slik sett har undersøkingsområdet fellestrekk med aktivitetar påvist på og ved «steinkledde» bergknausar i Sverige i same perioden (jf. Lönn, Apel \& Brorsson, 2014).

Anlegg 14 (jf. Fig. 3 og 5) er tolka som ei kremasjons-grav/-deponering, lokalisert øvst på kollen. Under ei låg, uforstyrra steinlegging utan overflatemarkering vart det funne brent masse med om lag $200 \mathrm{~g}$ kremerte skjelettdelar frå menneske og nærmare 200 fragment frå eit tynnvegga, kvartsmagra hankekar som typologisk sett tilhøyrer perioden romartid-folkevandringstid. Det osteologiske materialet er analysert nærmare (jf. Denham, 2015), og fleire av fragmenta har diagnostiske trekk som sannsynleggjer at dei stammar frå ein vaksen, mellomaldrande person. Funnet av eit mellomfotsbein som ikkje var ferdig samanvakse, kjem derimot etter alt å døme frå eit barn eller tenåring, så truleg var det
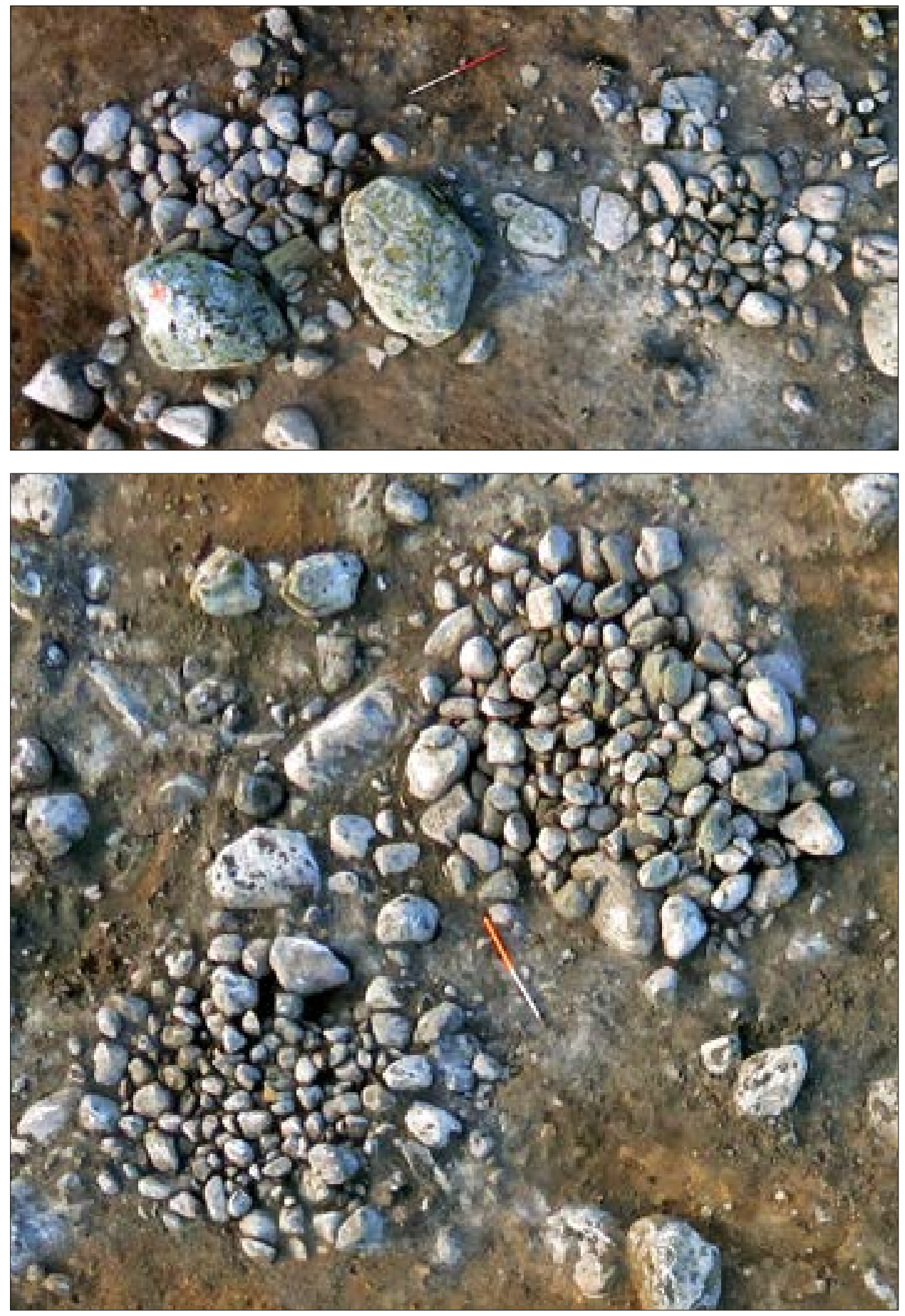

Fig. 5. Anlegg 14 (til høgre), anlegg 12 (til venstre) og anlegg 950 (open steinlegging til venstre ved blokkstein). Foto mot N. Foto: AM, UiS. Fig. 5. Structure 14 (right), structure 12 (left) and structure 950 (kerb to the left of boulder with red marking). Facing $N$. Photo: AM, UiS.

Fig. 6. Anlegg 10 (til høgre) og anlegg II (til venstre). Foto mot NNV. Foto: AM, UiS.

Fig. 6. Structure 10 (right) and structure II (left). Facing NNW. Photo: AM, UiS. 
deponert restar frå to individ her. Dette er eit interessant døme, som aktualiserer ein viktig fagdebatt rundt ulike former for deponeringar av fragment frå døde menneske (jf. s. 50-51). Anlegget vert omtala nærmare seinare i teksten, særleg i samband med ei kjeldekritisk vurdering av ${ }^{14} \mathrm{C}$-dateringar frå Orstad. I røysa Anlegg 10 (jf. Fig. 6) blei det også påvist noko brent skjelettmateriale frå menneske, medan dei andre steinsamlingane ikkje hadde klåre spor etter verken menneske eller deponerte gjenstandar. Blant dei «tome» anlegga var det nokre som verka meir intensjonelt oppbygde enn andre. I utgravingsrapporten (Bjørdal \& Rødsdalen, 2017) er det forsøkt å skilje desse, definert som «anlegg utan grav» (jf. Wangen, 2009, s. 11), ut frå dei anlegga som framstod som enklare og meir diffuse, definerte som «ryddingsrøyser» eller «uavklarte anlegg».

Seinare i artikkelen vert sider ved fasane prosjektplanlegging og førearbeid, feltarbeid og etterarbeid diskuterte, med det for auget å trekkje lærdom av dette møtet på Orstad mellom kulturminne og forvalting, men først vert fokus retta mot korleis ein møter slike lokalitetar og enkeltminne i forsking og forvalting.

\section{Om «røyser» i teori og praksis}

Det høver her å klargjere nokre sentrale omgrep som vert nytta gjennom artikkelen. Majoriteten av definisjonane er henta frå Vivian Wangen (2009) sitt verk om gravfeltet Gunnarstorp i Østfold. Ho legg særleg vekt på at omgrepa skal skildre konstruksjonselement; det er trekk ved oppbygginga av anlegget som kan påvisast, målast og teljast som bør vere styrande for kategoriseringa, ikkje forskaren sine tankar om sannsynleg funksjon. Denne målsetnaden om mest mogleg presis, objektiv og nøytral skildring av anlegga kan likevel ikkje lausrivast frå den enkelte arkeologen sitt personlege utgangspunkt, tolkingar vil vere påverka av faktorar som tidlegare erfaringar med liknande kontekstar og gjeldande normer innan faget. Dette grunnleggande dilemmaet vert ein ikkje kvitt. Ein utveg for å skape høveleg vitskapeleg kvalitet på arbeidet er etter mi meining å kombinere presis og oversynleg datainnsamling i feltsituasjonen med klargjerande informasjon i rapporten om kva slag refleksjonar og vurderingar arkeologen gjorde seg før, under og etter den aktuelle undersøkinga. Omgrepet «røys» er mykje brukt innan forvalting og forsking, men sjeldan så presist som hos Wangen (2009, s. 154); «Anlegg som er bygget av fleire lag stein, og som har en hvelvet profil». Ho skil mellom to typar røys, høvesvis med og utan grus og jord. Det følgjer logisk av dette at det finst andre typar av slike konstruksjonar enn røys, og ei av desse er «steinlegging» (Wangen, 2009, s. 154-155). Denne skil seg frå «røys» på fleire vis, mellom anna ved å kunne innehalde berre eitt lag med stein, og ved ikkje å ha kvelva profil. Dei ulike anleggstypane vert vidare karakteriserte av delelement, som til dømes bruk av sorterte stein etter visse storleikar og særskilte markeringar av ytterkant eller sentrum. For å unngå uklare omgrep som «tome graver», nyttar Wangen (2009, s. 11) kategoriane «gravanlegg» (den synlege markeringa bygd over staden der restar av den døde er deponert) og «anlegg utan grav». «Steinkonstruksjon» (jf. t.d. Forsman \& Victor, 2007; Röst, 2016) og «intensjonell steinsamling» vert nytta med same meiningsinnhald i denne artikkelen. Desse omgrepa har den styrken ved seg at dei begge skildrar bruk av stein som prosess og resultat, utan å framstå som i seg sjølv styrande på den vidare tolkinga av kjeldematerialet i same grad som til dømes «røys» og «steinlegging». Eg nyttar «intensjonell steinsamling» for å understreke at det ikkje dreier seg om eit reint naturskapt objekt.

Skiljet mellom korleis delane av eit anlegg framstår ved undersøkingstidspunktet, og kva rolle anlegget har hatt i førhistoria, burde vere så grunnleggjande kjeldekritisk sett at det ikkje var naudsynt å fokusere særleg på dette innan arkeologifaget på 2000-talet. Men slik er det ikkje, fortsatt hender det at anlegg vert registrert og klassifisert med utgangspunkt i kva som tradisjonelt har blitt sett på som «passande» form, storleik og lokalisering i landskapet. Dette skjer trass i at Wangen slett ikkje er einsam om å ha påvist klare veikskapar ved denne framgangsmåten (jf. t.d. Lillehammer, 1996; Dommasnes, 1997; Rødsrud, 2004; Häggström, 2007; Hansson, 2008; Bortheim \& Dahl, 2014; Petersson, 2015).

Det kan vere svært komplekst å tolke oppkomsten av intensjonelle steinsamlingar. Det har vist seg at tradisjonelle framgangsmåtar for å sortere og kategorisere anlegga, ikkje fungerer fullgodt for å skilje mellom anlegg for grav eller rydding. Det er ikkje nok med eit snevert fokus på ytre og synlege, såkalla «okulære» kriterier, som storleik på høvesvis røys og enkeltsteinar, form, og plassering i terrenget (Hansson, 2008, s. 162). Ein har døme på situasjonar der anlegg, som på førehand er vurdert til å vere klåre og uplyndra gravminne, har vore «tome» (utan bevarte gravgåver eller restar etter den døde), og motsette tilfelle, der gravkontekstar har dukka opp i meir diffuse steinsamlingar, gjerne inntil større jordfaste steinar eller flyttblokker (Röst, 2016, s. 189-190). Anlegga, slik dei framstår ved utgravingstidspunktet, er sluttprodukt av mange tusen år med formasjonsprosessar. Dette kan inkludere både 
konstruksjon og dekonstruksjon, for det kan ha vore like relevant og «rett» å byggje om eller demontere ein steinkonstruksjon som det var å skape han i første omgang. «Manglande» steinar i kantkjede og steinlegging eller andre «avvik» frå ein kategori sitt mønster, treng såleis ikkje stamme frå skader påført i nyare tid (Röst, 2016, s. 277-278), men allereie i «stenbärarna» (jf. Karlenby et al., 2011) sin periode.

Val av metodar for utgraving og dokumentasjon har kjeldekritisk sett avgjerande påverknad på datainnsamlinga. Eit anlegg som i planleggingsfasen er tolka som ryddingsrøys, har tradisjonelt blitt grave med ein metodikk som er så rask og røff (snitting med gravemaskin og fokus på prøver frå tverrprofil) at ein neppe vil kunne finne eventuelle teikn som talar i mot den innleiande tolkinga. Det oppstår såleis ein sirkelargumentasjon, der ein ofte finn det ein har bestemt seg for å leite etter (Hansson, 2008, s. 164). Mykje talar dessu$\tan$ for at det er meir fruktbart å studere førhistoriske kontekstar og kompleksitetar enn berre å stadig jakte på klare graver og «ikkje-graver». Her finst det «gråsoner», «komplekse røyser» og «steinkledde berg», med anlegg som er utfordrande og stimulerande å reflektere rundt (jf. Hansson, 2008, s. 166; Lönn et al., 2014, s. 7-9 og 123-131; Petersson, 2015, s. 47; Röst, 2016, s. 35).

Både ritual, gravleggingar og former for røysbygging kan ha hatt utgangspunkt i eit ønske om å markere tilhøyre til ein utvald del av landskapet, og det var truleg ikkje så avgjerande at det faktisk blei lagt ned restar frå døde i kvar einskild røys (Sjölin, 2015, s. 89). Slike særlege stadar, med ein variasjon av anlegg som har fungert saman, kan sjåast som «monument» (jf. Rødsrud, 2004, s. 277, 281-282; Häggström, 2007, s. 74; Wangen, 2009, s. 99-104, 124 og 136-137). Nokre døme frå ulike delar av Noreg kan illustrere slike stadar. Innan Kvassheimgravfeltet i Hå kommune i Rogaland blei det observert eit omfattande tal steinbygde anlegg utan funn innan same område som dei funnførande gravanlegga (Lillehammer, 1996, s. 31-35). Av dei undersøkte anlegga med rund form, var halvparten funntome. Nokre av desse «komplekse røysene» (jf. Petersson, 2015, s. 47) kan ha kome til som rydningsrøyser, men det har ikkje vore mogleg å skilje ut eventuelle slike. Dei funntome anlegga er ikkje daterte, medan dei eldste klare og daterte gravene på staden er frå sein førromersk tid og eldre romartid. Denne tidfestinga er interessant, sidan dateringar frå fleire liknande, norske lokalitetar, inkludert Orstad, stammar frå førromersk tid og tilgrensande periodar (jf. Dommasnes, 1997; Wangen, 2009: Bortheim \& Dahl, 2014; Bjørdal \& Rødsdalen, 2017). I mange av dei steinbygde anlegga på lokaliteten
Gunnarstorp i Sarpsborg kommune i Østfold blei det ikkje funne spor etter gravleggingar - dei var «anlegg uten grav» (Wangen, 2009). Ved utgravingar på Vereide i Sogn og Fjordane er det påvist funntome hauganlegg. «Vi kan i virkeligheten ikke avgjøre om begravelsene var brente eller ubrente, eller om begge former ble praktisert, ikke en gang om den døde faktisk ble fysisk begravet her [..]» (Dommasnes, 1997, s. 165). Anlegga er likevel tolka som gravkontekstar i staden for ryddingsrøyser, mykje på grunn av den generelle likskapen med andre, klare gravminne og fordi anlegga var nøye oppbygde. Desse trekka som er nemnt her, er attkjennelege i materialet frå Orstad-lokaliteten. Den geografisk sett nærmaste, relevante undersøkinga for Orstad-utgravinga i 2014 sin del, vart utført på og ved Håbakken i Klepp kommune, berre om lag ein kilometer SV om Orstad. Her vart tilnærma alle dei påviste røysene tolka som spor etter rydding. Men eitt røysanlegg er skilt ut og forstått som «en gravrøys uten grav» (Hemdorff, 1987, s. 235); kategorien «gravrøys» er tufta på kriterier som storleik, form, plassering i terrenget og påvisinga av ei tilhogd steinblokk sentralt $i$ anlegget, medan presiseringa «uten grav» kjem av mangelen på funn av gjenstandar eller skjelettrestar.

Auka merksemd mot landskap, kontekst og uavklart (fleir-)bruk av kulturminne, betyr ikkje at ein bør nedprioritere arbeidet med å søkje kunnskap om gravleggingar og gravskikk blant restane etter dei steinbygde anlegga. Eg forstår gravskikk som all aktivitet tilknytta ei gravlegging, både før, under og etter sjølve deponeringa av den avlidne og eventuelt tilhøyrande gjenstandar. Dette høver overeins med Vivian Wangen sin definisjon av omgrepet (jf. Wangen, 2009, s. 11). Det er krevjande å slå fast eksakte «grenseverdiar» for når ein kan seie å ha påvist ei gravlegging, dette gjeld både kvantitativt (rett mengde) og kvalitativt (rett type). Ei sak er at eit heilt funntomt, men systematisk oppbygd, anlegg kan ha fungert som gravminne - men kva med eit anlegg som inneheld anten svært lite av «rett» materiale, som kremert menneskebein (jf. t.d. Bjørdal \& Rødsdalen, 2017), eller eit klart innslag av eit materiale som er meir «funksjonsdiffust» og lite statusindikerande, som grovmagra, spreidde leirkarskår? (jf. t.d. Bortheim \& Dahl, 2014). Dette er ei kjeldekritisk utfordring, der både gamle og nye formasjonsprosessar har påverknad på kva arkeologen finn og forstår. Somme forskarar vel difor å snakke om deponeringar i staden for graver og gravskikk, som til dømes Anna Röst i sin studie av lokalitetar frå Sörmland i Sverige frå yngre bronsealder og førromersk tid. Ho meiner at ein må «[...] acceptera att deponerande av mänskligt 
benmaterial ibland - och ibland inte - förekommer som en integrerad del i en praktik att konstruera och bruka anläggningar i sten» (Röst, 2016, s. 21). Det vert for omfattande å gå inn på ein grundig diskusjon på dei aktuelle elementa i dette her (jf. t.d. Kaliff, 1997, 2009), i staden skal søkjelyset avgrensast til nokre aspekt ved kremasjonsgraver.

Ein kremasjon av ein vaksen person bør gjennomsnitteleg gje rundt $2 \mathrm{~kg}$ med brente beinfragment, men ofte finn ein langt mindre enn dette i branngraver (Holck, 1996, s. 83). Er noko av det opphavelege beinmaterialet blitt nedbrote og borte (jf. Arcini, 2007; Sjöling, 2007) og/eller har berre ein del av den totale beinmengda som var tilgjengeleg etter kremasjonen blitt lagt ned i gravgøymet? Det er mogleg at beinrestane har blitt intensjonelt fordelt på eit slikt vis at berre noko av materialet vart prioritert til å leggjast ned i røysa. I så fall er det ei utfordring å avgjere kva som bør forståast som «grav», og kva som heller var ei anna form for kultisk plassering av bitar frå ein død person. Dette opnar opp for at kompleksiteten ved beindeponeringar er enno større enn det ein tradisjonelt har reflektert rundt. Dei «halmstråa» som små mengder av kremerte menneskebein har fungert som for grav-søkjande arkeologar, kan i røynda stamme frå det Martin Hansson kallar «något annat» (Hansson, 2008, s. 165). Kan eventuelt eit menneske slik ha fått fleire «gravleggingar» - og var sjølve transformasjonen (kremasjonen, og eventuell vidare bruk av dei brente beina i kultiske handlingar seinare) viktigare enn éin, endeleg kvilestad (jf. Kaliff, 1997; Oestigaard, 1999; Artelius, 2000; Röst, 2016)? Funn av «for små» beinmengder, og av bein på «feil stad» i røyser, bør kanskje heller forståast som resultat av aktivitetar med bein, ikkje som arkeologen sine sårt etterlengta prov på gravlegging (Rødsrud, 2004, s. 283-285; Röst, 2014, s. 140).

Den følgjande delen av artikkelen vil spesifikt presentere og drøfte sider ved den arkeologiske undersøkinga som i 2014 vart utført på Orstad. Denne utgravinga er klart relevant for tematikken omtala ovanfor, både når det gjeld prosjektplanlegging, feltarbeid og tolkingar av det påviste materialet.

\section{Orshaugprosjektet: eit døme på utgraving av komplekse røyskontekstar}

\section{Fasen for utgravinga}

Prosjektplanen, med tilhøyrande budsjett, la føringane for den arkeologiske undersøkinga (jf. Arkeologisk museum, UiS, 2013). Dette var dei gjeldande styringsdokumenta for prosjektleiaren. Det må her nemnast at det var artikkelforfattaren som hadde denne aktuelle prosjektleiarrolla, så evalueringar i den følgjande teksten om prosess og resultat tilknytta feltarbeidet er å oppfatte som konstruktiv sjølvkritikk.

Prosjektplanen kom kort sagt fram til at éi mogleg gravrøys skulle undersøkast totalt ved handkraft, og fem ryddingsrøyser skulle delundersøkast ved maskinell snitting med påfølgjande dokumentasjon og prøveuttak frå utvalde profilar. Ei flate, som truleg var rydda i bronsealderen, blei prioritert for maskinell avdekking med tilhøyrande undersøking, dokumentasjon og prøvetaking av busetnadsspor.

La oss først sjå nærmare på korleis ein kom fram til desse prioriteringane og deretter diskutere kva grep som fungerte meir eller mindre godt sett i lys av erfaringane frå feltarbeidet og dei påfølgjande analysene og tolkingane av det påviste materialet. Den grunnleggjande målsetnaden med dette er å få fram lærdom som kan overførast til framtidige prosjekt knytt til liknande lokalitetar.

Prosjektplanen for Orstad var i stor grad tufta på arkeologisk og arkeobotanisk fagkunnskap henta frå sjølve lokalitetane og frå det omkringliggande landskapet. Hovudfokuset var på registrerte og undersøkte faste kulturminne og på innleverte gjenstandsfunn frå dette området i Klepp kommune. Dette burde vere eit over gjennomsnittet godt utgangspunkt for planlegging, sidan ein hadde både ei ny registrering frå 2012 av dei aktuelle lokalitetane og fleire tidlegare, relevante undersøkingar i nærområdet.

Undersøkingar utført av Arkeologisk museum i Stavanger (AmS) på 1980- og 1990-talet (m.a. Hemdorff, 1987; Hemdorff \& Sageidet, 1997) hadde funne klare spor etter busetnad og jordbruk frå tidsspennet yngre steinalder-førromersk tid, og dette blei i prosjektplanen framheva som gode indikatorar på kva som kunne påtreffast innan undersøkingsområdet for 2014-utgravinga.

Rogaland fylkeskommune (RFK) si registrering i 2012 av dei to aktuelle lokalitetane (Vivås, 2012) fann både ei rydda flate, ryddingsrøyser og minst éi mogleg gravrøys. Røysene vert omtala som låge og lite synlege i det graskledde landskapet, og dei hadde varierande form og storleik. Ei delvis avtorving av den eine «røysa» på Id. 157479 påviste ein rund og relativt flat steinpakning. Tre av dei sju registrerte, steinbygde anlegga på denne lokaliteten vart klart vurderte til å kunne vere «noko anna» enn ryddingsrøyser (jf. Hansson, 2008, s. 165). Argumentasjonen for dette framstår som basert på både a) tradisjonelle tankar rundt storleik og form, der gravrøyser truleg er større og meir systematisk bygde enn ryddingsrøyser; «Denne fremstår også som høyere 
enn resten av strukturene. Størrelse på røys og stein [jamn steinstorleik på ca. 25-30 cm i diameter i denne strukturen 7.7 indikerer sortering, min kommentar] trekker tolkningen i retning av gravrøys» (Vivås, 2012, s. 12), og b) på meir praktisk-funksjonelle vurderingar: «For lav og flat til å være rydningsrøys?» (Vivås, 2012, s. 37). Det vert vidare kommentert at både toppen og vestsida av ein liten kolle her verkar rydda i eldre tid. Den andre lokaliteten, Id. 157480, låg like ved. På ei rydda flate her registrerte ein to steinpakningar tolka som ryddingsrøyser. Den eine av dei vart undersøkt nærmare ved avtorving av to sjakter og uttak av ei jordprøve frå botnen av torvhorisonten. Materiale frå denne prøva er ${ }^{14} \mathrm{C}$-datert til byrjinga av yngre bronsealder, og ein tolkar denne dateringa til å avspegle tidspunktet for rydding av flata.

I prosessen mot den ferdig utforma prosjektplanen har det skjedd noko. No vert berre éi av røysene (den klaraste 7.7, omtala som Anlegg 10 ved undersøkinga i 2014), akseptert som noko mogleg anna enn rydda stein (jf. Arkeologisk museum, UiS, 2013). Kvifor har undringa rundt dei andre «for låge og flate» røysene falle bort? Dette kan ha samanhang med erfaringar frå tidlegare undersøkingar i området. Undersøkingane hadde omfatta fleire røyser - men desse var anten rutinemessig tolka til rydding eller som skuffande tome. Gode resultat frå arkeobotaniske undersøkingar i området gav truleg ei sterkare fagleg interesse for røyser som indikatorar på pionerjordbruk. Det fanst såleis ein kombinasjon av både negativ og positiv trekkraft mot eit syn på røysene som «ikkje-graver». Moglegvis medførte dette også at potensialet for å finne fleire røyser enn dei allereie registrerte, noko som ikkje var urealistisk basert på kor låge og overgrodde røysene var, ikkje blei vektlagt i prosjektplanen. Det var ikkje budsjettert med full maskinell avdekking av den mest røysrike lokaliteten Id. 157479, noko som allereie i utgangspunktet klart reduserte sjansen for å oppdage låge, steinbygde anlegg og andre spor som kokegroper eller kulturlag. Planen diskuterer heller ikkje i særleg grad tematikken «komplekse røyser». Dette styringsdokumentet for utgravinga i 2014 verkar såleis noko snevert og fastlåst i tradisjonelle tolkingar og metodikk. Dette bør forståast som resultat av ein omfattande forvaltingsprosess med sine normer og sedvaner, der klare og skilde kategoriar som «gravrøys», «ryddingsrøys» og «busetnadsspor» verkar høvelege og ønskelege.

I tida rett før utgravinga tok til, var det sett av noko ressursar til den utvalde prosjektleiaren og feltleiaren sitt førearbeid. Dette omfatta mellom anna ei kort synfaring til undersøkingsområdet. Her reflekterte ein rundt kollen på Id. 157479 sitt potensial som markør i terrenget og som «monument» med både synlege og ikkje-synlege kulturminne tilknytta seg, ein tematikk som ikkje var særleg vektlagt i prosjektplanen.

Utgravingsresultata frå 2014 gjev eit anna bilete av situasjonen enn det ein kunne forvente utifrå planleggingsfasen. Sider ved arkeologisk utgraving og etterarbeid vert diskuterte i dei komande avsnitta, først står søkjelyset på feltarbeidsfasen.

\section{Feltarbeidsfasen}

Inspirert av dei nylege erfaringane frå AM si undersøking av låge steinkonstruksjonar på Tjemslandsmarka $\mathrm{i}$ Hå kommune (Bortheim \& Dahl, 2014), valde prosjektleiar for Orstad-undersøkingane å maskinelt flateavdekke/-avtorve eit større, samanhengande areal på og ved kollen på Id. 157479 enn det som stod nedskrive i prosjektplanen. Dette grepet, gjort i samråd med nærmaste leiar på $\mathrm{AM}$, påviste spor etter tre gangar fleire steinkonstruksjonar enn ved registreringa i 2012.

Ein gjennomførte også den planlagde flateavdekkinga av det rydda området på Id. 157480. Dette arealet viste seg å innehalde langt færre busetnadsspor (i alt ein kokegrop og to steinsamlingar) enn det var budsjettert for å finne (ca. 40 stk. anlegg).

Situasjonen etter avslutta maskinbruk var såleis slik at fleire av føresetnadane for prosjektplanen var endra når det galdt tal på, og typar av, anlegg. Det lét seg gjere å få godkjent ei viss omprioritering av ressursbruken frå busetnadsspor til «røyser». Men det fanst likevel klare praktiske og metodiske utfordringar ved den vidare gjennomføringa av utgravinga, og dei mest sentrale vert diskuterte nærmare nedanfor.

Etter at ein hadde fått oversyn over enkeltanlegg og den samla kulturminnekonteksten ved hjelp av digital innmåling og dronefoto, blei dei ulike anlegga kategoriserte og prioriterte. Kriteria for kategoriseringa var tradisjonelt nok knytt til storleik, form, innhald/oppbygging, lokalisering og funnkontekst. Ein visste frå tidlegare undersøkingar i Rogaland at det fanst ein variasjonsrikdom blant «røyser», men likevel kjendest det rett å leite etter indikatorar på anten gravlegging eller rydding. Det var dette skiljet som vart oppfatta som det fagleg viktigaste i denne fasen av utgravinga. Avvik frå desse to tolkingsalternativa var såleis i utgangspunktet ei form for kompleksitet eller «problem» som ein helst ville unngå i ein pressa feltsituasjon.

All utgraving føregjekk med handkraft. Maskinell snitting vart vurdert til å vere ein for grov metodikk til å fange opp funn og konstruksjonsdetaljar, og det var ikkje sett av ressursar til å ha maskinhjelp tilgjengeleg 
under den manuelle utgravinga. Fråværet av slik hjelp hadde fleire negative konsekvensar. Den generelle fysiske slitasjen på feltarkeologane blei større enn det som var tilrådeleg. Mange hundre kilo med stein måtte plukkast opp og fraktast bort, og denne prosessen var slitsam og gjekk sakte. Somme steinar var for store til å flyttast manuelt, noko som medførte at fleire av dei steinbygde anlegga ikkje blei totalt demonterte. Særleg galdt dette steinar i kantmarkeringar. Desse attverande steinane blei eit kjeldekritisk problem, sidan det er uavklart i kor stor grad dei kan ha skjult konstruksjonsdetaljar eller gjenstandsfunn (jf. Wangen, 2009, s. 29). Det er ikkje uvanleg at deponeringar vert påviste ved eller under slike steinar, noko som kan forståast som ei vektlegging av fragmentering og grenser hos dei fortidige aktørane (Röst, 2016, s. 163-167).

Det vart berre i avgrensa grad nytta vass-sålding ved denne undersøkinga. Dette kom både av dårleg tilgang på vatn i felt, og av at ei auka satsing på slik sålding ville medføre mindre tid til å grave og dokumentere anlegg. Ein prioriterte sålding av to typar kontekstar. Dette var restar etter moglege kulturlag eller branngraver innan steinbygde anlegg og eit areal på toppen av kollen med klart innslag av flintmateriale frå steinalder.

Dokumentasjon føregjekk ved hjelp av ein kombinasjon av digital innmåling, handteikning, fotografering og skriftlege notat. Dronefotografering vart utført i tre omgangar undervegs i undersøkingsprosessen. Slik dokumentasjon letta klart tolkingsarbeidet, både for enkeltanlegg og for den samla kulturminnekonteksten i landskapet.

Dei knapt tilgjengelege ressursane gjorde det urealistisk å undersøkje samtlege steinbygde anlegg ved hjelp av «single context recording», med gradvis demontering og dokumentasjon frå yngste til eldste formasjonsprosess med kontekstskjema og matriser. Denne arbeidsmåten vart difor berre nytta på nokre utvalde strukturar, mellom anna den moglege gravrøysa frå prosjektplanen, Anlegg 10. Ein ville ikkje funne det vesle fragmentet av brent menneskebein i Anlegg 10 utan kombinasjonen av slik metodikk og vass-sålding. Samstundes fanst det ein del praktiske utfordringar, hovudsakleg knytt til tidsbruk og tolking. Framdrifta ved bruk av slik demontering og dokumentasjon var tydeleg saktare enn ved dei andre nytta metodane (jf. nedanfor), det tok rundt dobbelt så lang tid. Det oppstod samkøyringsproblem når fleire personar skulle jobbe saman. Dette kom av høgare detaljfokus ved slik metode og av varierande erfaringsgrunnlag hos dei involverte feltarkeologane. Den sterke vektlegginga av å påvise og skildre formasjonsprosessar gav klare utfordringar når det galdt overtolking, som kunne føre til at relativt diffuse trekk ved anlegget vart oppgraderte til klare konstruksjonselement.

Dei andre framgangsmåtane for utgraving og dokumentasjon var variantar av høvesvis tilpassa «single context recording» og meir mekanisk-stratigrafisk utgraving. Éin framgangsmåte gjekk ut på å først grave ut og dokumentere den eine halvdelen av anlegget, deretter fokusere på tverrprofilen og eventuelt ta ut prøver frå denne, før ein til slutt grov ut den andre halvdelen og sluttdokumenterte heile anlegget. Dersom det vart påvist klare lagskiljer, vart desse unders $ø$ kte kvar for seg, elles blei steinfyllet plukka ut i tilnærma mekaniske lag ved fjerning $\mathrm{i}$ «runder» av nivå med synleg stein. Denne metoden hadde nokre sterke sider; det gjekk relativt raskt å fastslå om det fanst klare konstruksjonsdetaljar eller funnmateriale i den eine halvdelen av anlegget, ein fekk oppretta ein tverrprofil som gav godt oversyn over dei vertikale tilhøva, og det gjekk greitt å samarbeide fleire personar om utgraving og dokumentasjon. Ein annan brukt variant var å fjerne all synleg stein på heile anlegget samstundes. Dette gav betre oversyn og kontroll av det horisontale aspektet, men ein fekk ikkje nokon tverrprofil. Det blei også brukt ei mellomløysing, der ein demonterte steinfyllet på begge sider av ein tverrprofil etter om lag tilsvarande steinnivå. Å jobbe slik med faste profilar, og meir eller mindre mekaniske nivå, kan ha svekka sjansen til å oppdage både kontekstar og funnmateriale. Til dømes viste arbeidet med Anlegg 10 etter «single context»-metoden at delar av det same konstruksjonselementet kunne vere synleg på ulike nivå innan steinfyllet.

Etter kvart som feltarbeidet gjekk framover, skjedde eit brot med den vande tankegangen rundt anten «gravrøys eller ryddingsrøys». Ein opna i større grad opp for og aksepterte at anlegg kunne vere «noko anna» enn berre desse to moglegheitene, og i forlenginga av dette fanst tanken om at dette «andre» kunne ha stor fagleg verdi i seg sjølv. Denne endringsprosessen skjedde på grunn av betre innsyn i nyare forsking sine omgrep og kategoriseringskriteriar, men også fordi eigne erfaringar frå utgravinga gav grobotn for aktiv refleksjon over korleis desse anlegga hadde kome til. Medan ein i starten av Orstad-undersøkinga brukte det generelle omgrepet «røys» om samtlege påviste steinbygde anlegg, så utvikla språket seg undervegs til å bli meir spesifikt og presist ved at ein tok i bruk både fagleg kjende omgrep som «steinlegging», «steinpakking» og «brulegging» (jf. Wangen, 2009, s. 154-155) og meir sjølvlaga skildringar som «plattform» og «steinsett grop». Det var ein dynamisk prosess, der auka kunnskap og erfaring 
leidde til endringar i synet på kva anlegg som burde ha høgast prioritet, og på kva metodikk som fungerte best i høve til dei ulike objekta.

Det blei stadig klårare at representativitet var ei utfordring. Sidan dei steinbygde anlegga var så varierte i form og oppbygnad, og funnmaterialet derifrå var lite, blei det krevjande å halde fast på grunntanken om å undersøkje eit representativt utval av anlegga. Dette vart så forsøkt kompensert for ved å undersøkje nokre fleire anlegg. Her vart eit sentralt spørsmål ved prioritering sett på spissen; burde ein helst undersøkje få anlegg svært detaljert eller derimot fleire anlegg på mindre grundig vis? Denne utfordringa vert kommentert nærmare seinare i teksten.

Feltarkeologar og fagspesialistar frå AM tok i samarbeid ut fleire typar prøvemateriale, både arkeobotaniske makrofossilprøver, pollenprøver og prøver for jordkjemiske analyser (jf. Hollund \& With, 2015; Ahlqvist \& Shekari, 2017). Tanken bak det særlege fokuset på jordkjemi var at deponeringar (som gravlegging, offer o.l.), kan endre grunnstoffsamansetnaden lokalt. Slik kan ein arkeologisk kontekst skilje seg ut i høve til dei nærliggande, naturskapte massane i grunnen. Fråværet av funnmateriale frå anlegga gjorde at uttak av jordkjemiske prøver vart prioriterte opp undervegs i utgravinga. Håpet var at desse prøvene kunne innehalde informasjon som på noko vis kunne kompensere for denne funnfattigdomen. Resultat frå dei ulike prøvetypane vert kommentert seinare i samband med etterarbeidsfasen, her følgjer ei kort utgreiing om sider ved sjølve prøveinnsamlinga.

Sidan dei steinbygde anlegga vart undersøkte på noko ulikt vis, varierte føresetnadane for prøveuttak. For makrofossil- og pollenprøver, var situasjonen at nokre prøver vart innhenta frå permanente profilar i anlegg. Andre slike prøver blei teke ut av steinbygde anlegg først etter at steinfyllet der var fjerna. Dette skjedde ved at ein grov små prøvestikk/«profilgroper» gjennom bevart botnlag eller forsegla, fossil markoverflate ned til klar, naturskapt undergrunnsmasse og deretter tok ut prøver frå profilsnittet (jf. Ahlqvist \& Shekari, 2017, s. 11). Det blei også samla inn makrofossil- og trekolprøver frå spesifikke strukturar, tolka som restar etter kulturlag eller branngrav, undervegs i utgravinga av steinfyllet. Dei jordkjemiske prøvene (jf. Hollund \& With, 2015) vart samla inn frå fleire intensjonelt skapte lag og frå eit truleg anrikingslag på Felt 1.

\section{Etterarbeidsfasen}

Utgravinga på Orstad var ferdigstilt hausten 2014 Den påfølgjande prosessen med handsaming av doku- mentasjonsmateriale og funn, analysearbeid og tolkingar, tilhøyrer etterarbeidsfasen.

Ei utfordring i dette stadiet var variasjonen i utgravingsmetode og dokumentasjonsstandard for dei ulike steinbygde anlegga. Ein omfattande gjennomgang av alt materiale frå feltarbeidet viser eit blanda bilete. Mykje held tilfredsstillande fagleg standard etter føresetnadane, men det finst også døme på høvesvis for lite og for mykje dokumentasjon og tolkingsinnsats. Ein har somme tider gått for raskt fram, og andre gonger dvelt i overkant mykje ved detaljar og diffust informasjonspotensial.

Bruken av standardiserte, fagleg oppdaterte omgrep og definisjonar for dei steinbygde anlegga (t.d. «anlegg med/utan grav», «monument») blei først teke konsekvent i bruk i samband med etterarbeidet. Denne auka presisjonen i språk og analyse gav klart betre skildringar og tolkingar av materialet. Samstundes blei det tydeleg at dersom denne kunnskapen hadde blitt nytta systematisk tidlegare, i planlegging og feltarbeid, ville ein ha prioritert annleis og slik unngått informasjonstap.

Gjenstandsmaterialet frå utgravinga var både lite og skeivt fordelt. Dei to klart funnrikaste kontekstane var lokaliserte på om lag same stad, nemleg øvst på den vesle kollen. Dette var høvesvis flint frå eit steinaldersk aktivitetsområde og leirkarskår tilknytta ei kremasjonsgravlegging/-deponering frå romartid i steinlegginga Anlegg 14. Majoriteten av dei andre steinbygde anlegga inneheldt ingen gjenstandar i det heile, medan to slike anlegg (nr. 8 og 9) (sjå Fig. 7) hadde funn i form av flintgjenstandar knytt til seg. Formuleringa «knytt til seg» tyder at relasjonen gjenstand - anlegg her er uavklart, og begge desse anlegga er difor definerte som «Anlegg utan grav». Eit nærmare blikk på desse strukturane viser kor krevjande det kan vere å forstå formasjonsprosessar i samband med slike subtile kontekstar, og dette er informasjon som har overføringsverdi til andre undersøkingar.

Anlegg 8 og 9 låg rett ved sidan av kvarandre og var bygd opp med utgangspunkt i stor, jordfast stein (jf. Fig. 8). Begge hadde klare konstruksjonstrekk. I Anlegg 8 var det tydelegaste trekket ein ståande bautastein, medan det i Anlegg 9 fanst både ei særleg steinpakning plassert sentralt og inntil den jordfaste steinen og ei uregelrett kantkjede av større steinar. Det var krevjande å tolke kva som var påført ved bygginga av den øvre, mest synlege delen av anlegga, og kva som eventuelt tilhøyrde eldre anleggsfasar eller annan aktivitet på markoverflata. Godt nede i Anlegg 8 sin NV-del, i overgangen mellom eit sandlag og eit meir humushaldig lag, blei det funne ein tangespiss av flint av A1-type, 
Fig. 7. Anlegg 8 med reist stein in situ. Foto mot SSØ. Foto: AM, UiS.

Fig. 7. Structure 8, with stone standing upright in situ. Facing SSE. Photo: AM, UiS.

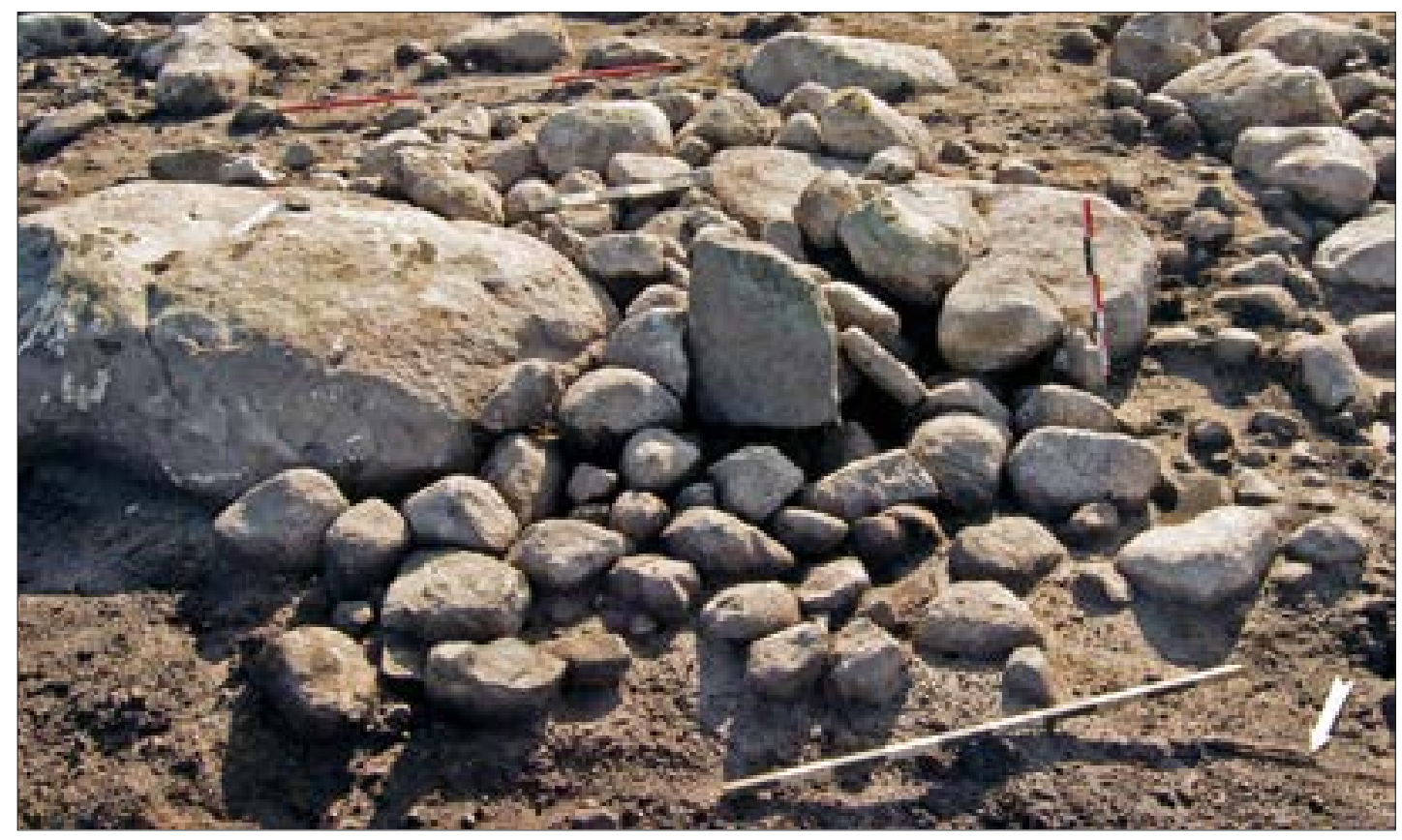

som typologisk kan daterast til første halvdel av yngre steinalder (ca. 4000-3000 f.Kr.). Spørsmålet er om pilspissen bør forståast som spor etter eldre aktivitet på staden utan relasjon til Anlegg 8, eller om han var deponert i anlegget? Det finst ikkje ${ }^{14} \mathrm{C}$-datert prøvemateriale frå Anlegg 8. Anlegg 9 omfatta fleire nivå med stein. Eit lyst sandlag dekte store delar av strukturen, dei fleste steinane låg anten i eller over denne sanden. Dette sandlaget kan ha vore intensjonelt påført, for det skilde seg ut frå podsollaget som fanst over store delar av lokaliteten. Det vart ikkje gjort funn innan sjølve Anlegg 9, men på utsida av steinar i kantkjeda vart det påvist både ein skiveskrapar av flint og eit flintavslag. Plasseringa utanfor kantkjeda gjer det enklare å tolke desse funna som restar frå ei anna og tidlegare hending enn konstruksjonen av anlegget, for dersom funna hadde blitt gjort innanfor eller under kantkjeda, ville dei ha vore høgaktuelle som deponeringar knytt til transformering, fragmentering og grenser (jf. s. 50). Ein ville ha vore tent med å ha sålda den undersøkte massen frå områda mellom røysene. Dette ville ha gjeve nyttig referanseinformasjon i samband med problemstillinga om flintfunna burde forståast som aktivt deponerte eller som tilfeldige innslag frå eit eldre aktivitetsområde på staden. Slik kunne ein fått hjelp til lettare å vurdere sider ved kompleksitetsomgrepet; tolkinga av Anlegg 8 og 9 ville ha sett annleis ut om ein på fagleg tryggare vis kunne argumentere for flintgjenstandane som anten intensjonelt plasserte eller som innblanda «bakgrunnsstøy».

Ei ${ }^{14} \mathrm{C}$-datering på forkola hasselnøtskal, funne $\mathrm{i}$ massar under steinar i Anlegg 9, indikerer aktivitet i romartid, denne dateringa høver for øvrig overeins med ${ }^{14} \mathrm{C}$-dateringa på brent menneskebein frå grava/ deponeringa i Anlegg 14. Materiale for og resultat av ${ }^{14} \mathrm{C}$-analyser er ein tematikk som vert diskutert nærmare i dei følgjande avsnitta.

Kva kan innhaldet i dei arkeobotaniske prøvene fortelje om enkeltstrukturar og samla kontekst på undersøkingsområdet? Rapporten om dei naturvitskapelege analysane av makrofossil og pollen (Ahlqvist \& Shekari, 2017, s. 24-25) fortel om klare spor etter førhistorisk jordbruk, både for husdyr og åkerdrift. Indikatorar på beiting og/eller fôrslått var til stades i alle dei prøvetekne strukturane, noko som kan høve godt overeins med ryddingsrøysfunksjon for somme av dei steinbygde anlegga. Det er ikkje påvist frø eller pollen frå korn, men funn av pollen frå vanlege ugrasplantar i åkrar gjev indirekte tydeleg teikn på at det fanst kornåkrar i nærmiljøet til anlegga. Pollenanalysane med tilhøyrande ${ }^{14} \mathrm{C}$-dateringar høver godt overeins med den eksisterande, meir generelle kunnskapen om vegetasjonshistoria i regionen for tidsrommet bronsealder-eldre jernalder (jf. Tabell 1).

Samstundes åtvarar rapporten om kjeldekritiske utfordringar: «Det er datert på brent hasselnøttskall og trekull av kortlevde løvtre, men i en sterkt bearbeidet kontekst som dette bør det tas forbehold om hvorvidt det daterte materialet daterer ønsket hendelse» (Ahlqvist \& Shekari, 2017, s. 25). Dette er eit heilt sentralt og avgjerande poeng for tolkingsarbeidet, både for arkeobotanikk og arkeologi. Materialtypane i seg sjølv er høvelege for ${ }^{14} \mathrm{C}$-datering, men kan dei sikkert knytast til dei formasjonsprosessane ein ønskjer å tidfeste? 


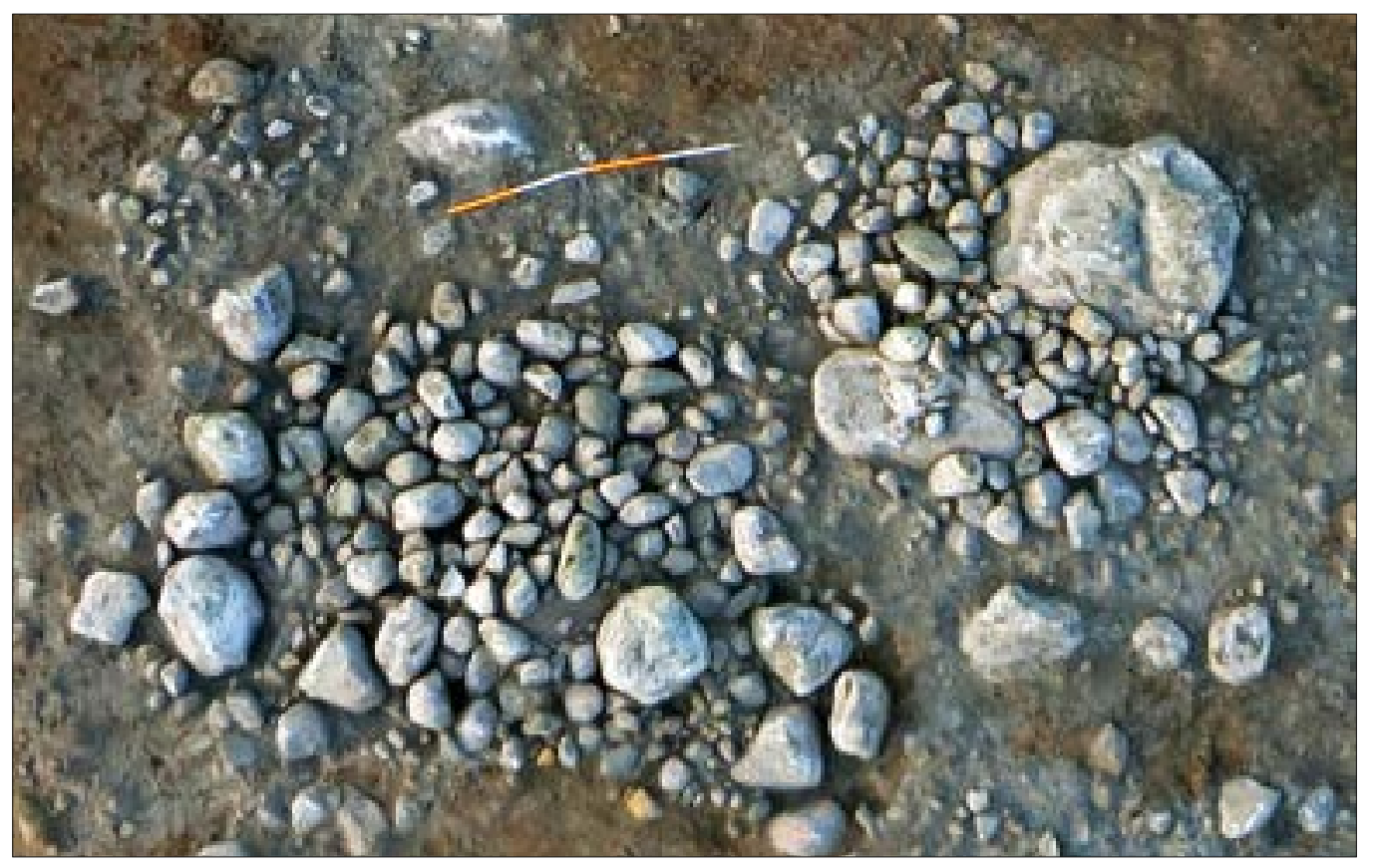

Fig. 8. Anlegg 8 (til høgre) og Anlegg 9 (til venstre). Foto mot $\mathrm{N}$. Foto: AM, UiS.

Fig. 8. Structure 8 (right) and structure 9 (left). Facing N. Photo: AM, UiS.

Dette representativitetsproblemet har ikkje lete seg løyse på tilfredsstillande vis for Orstadundersøkinga sin del. Dateringsresultata totalt sett spriker, med ytterpunkt i høvesvis seinmesolitikum og romartid og tyngdepunkt i bronsealder og førromersk tid (sjå Tabell 1). Med omsyn til eventuell bruk av steinkonstruksjonane for deponeringar av menneskerestar ville det ha vore ein klar fordel å kunne datere på diagnostiske beinfragment, slik Anna Röst har gjort i si forsking på nokre lokalitetar frå Sörmland (jf. Röst, 2016, s. 35, 107-108, 113-115). Men det store fråværet av bein på Orstad har medført at ein i stor grad har nytta botanisk prøvemateriale for ${ }^{14} \mathrm{C}$-dateringar av anlegga.

Dei ${ }^{14} \mathrm{C}$-dateringane som i utgangspunktet burde ha høgast kvalitet kjeldekritisk sett, stammar frå to typar kontekstar, nemleg eldgrop og kremasjonsgrav. Eldgropene (jf. Fig. 3 og 4, merka med raud farge) inneheldt materiale som truleg var brent in situ. Sjølv med fleire bruksfasar verkar det sannsynleg at den totale bruksperioden per grop ikkje var veldig lang.

Resultata viser at dei daterte eldgropene ikkje var i bruk samstundes, men innan eit vidt spenn frå eldre bronsealder til førromersk tid. Kremasjonsgrava/deponeringa i Anlegg 14 har dateringsresultat frå både brent menneskebein og forkola hasselnøtskal. Begge materialtypane er tekne ut av distinkte lag med brent masse i ein gravkontekst forsegla av ei steinlegging og upåverka av moderne inngrep. Trass i dette er dateringsresultata klart ulike - hasselnøtskalet er frå yngre bronsealder og beinfragmentet frå romartid. Samla sett er det utvilsamt dateringa på bein som høver best for å tidfeste gravlegginga, sidan det i same kontekst fanst leirkarskår som typologisk tilhøyrer perioden romartid-folkevandringstid. Døma frå eldgropene og kremasjonsgrava viser a) at det føregjekk menneskeleg aktivitet her i bronsealder og eldre jernalder som ikkje var direkte knytta til jordbruk, og b) at sjølv ein tilsynelatande urørt kontekst med kremasjonsrestar kan innehalde materiale som stammar frå ei anna tid enn kremasjonstidspunktet.

La oss gå vidare og sjå på ${ }^{14} \mathrm{C}$-dateringar frå det som i utgangspunktet var meir diffuse kontekstar innan sju av dei andre steinbygde anlegga. For to av strukturane, steinleggingane Anlegg 12 og 13, stammar dateringsprøvene frå tverrprofil. Desse steinleggingane hadde klare fellestrekk når det galdt lokalisering, form og oppbygging (jf. Fig. 3). Anlegg 13 har to daterte prøver. Den eine (forkola hasselnøtskal frå førromersk tid) er frå eit brunt, humushaldig siltlag under og mellom steinar i fyllet, og den andre (trekol frå overgangen seinneolitikum-eldre bronsealder) er frå eit siltlag (tolka som øvste del av naturskapt undergrunn) direkte under dette steinfyllet. Den eldste dateringa verkar å høve godt overeins med avsviing og rydding av landskapet i ei tidleg fase av jordbruket i området, medan den yngste dateringa truleg ligg nærmare tidspunktet for bygginga av sjølve steinlegginga. Anlegg 12 har éi datering, og denne stammar frå slutten av eldre bronsealder. Materialet er forkola hasselnøtskal frå eit siltlag under steinane i anlegget. Dette indikerer at Anlegg 12 og 13 kan vere konstruerte i same tidsperiode.

Tilhøva for dei andre steinkonstruksjonane vert no kort presenterte, i kronologisk rekkjefølgje etter anleggsnummer. Anlegg 2 har ei ${ }^{14} \mathrm{C}$-datering (forkola 
hasselnøtskal frå overgangen yngre bronsealder-førromersk tid) frå ein distinkt konsentrasjon sentralt i anlegget av brent masse med mykje trekol. Denne konsentrasjonen låg under steinfyllet, men over undergrunnen. Det er uavklart om dette laget har tilhøyrt anlegget eller om det stammar frå føregåande aktivitet. Anlegg 7 har ei ${ }^{14} \mathrm{C}$-datering (trekol frå seinmesolitikum) frå eit lag med trekol og nokre bitar av udiagnostisk brent bein, påvist sentralt og lågt $i$ anlegget. Oppkomsten av dette laget er uavklart, det er for diffust til å reknast som rest av kremasjonsgrav. Særleg det gamle dateringsresultatet avvik sterkt frå andre ${ }^{14} \mathrm{C}$-dateringar frå lokaliteten, og reint kjeldekritisk sett burde ein ha utført ytterlegare ei datering, på beinmaterialet. ${ }^{14} \mathrm{C}$-dateringa tilknytt Anlegg 9 (forkola hasselnøtskal frå førromersk tid) stammar frå jordmasse under ei steinpakking ved ein jordfast stein, lokalisert sentralt og nedst i anlegget. Anlegg 10 er definert som «anlegg med grav», grunna funnet av eit brent tåbeinfragment frå menneske. Anlegget har ei ${ }^{14} \mathrm{C}$-datering (forkola hasselnøtskal frå overgangen yngre bronsealder-førromersk tid) frå eit lag synleg i profilen av prøvegrop graven under steinfyllet (Ahlqvist \& Shekari, 2017, s. 8-9). Dette laget av silt, humus og sand låg direkte under steinane i anlegget og over eit lysare lag tilhøyrande naturleg undergrunnsmasse. Ein valde å ikkje bruke tåbeinfragmentet til datering, mykje fordi dette ville destruere det einaste provet på at det kunne vere ei form for gravleggingskontekst. Men den avgjerda har samstundes medført at det potensielt sett beste prøvematerialet ikkje har vorte analysert. Anlegg 11 er ${ }^{14} \mathrm{C}$-datert (trekol frå eldre bronsealder) på materiale frå eit lag rett under steinfyllet. Laget var synleg i profilen av prøvegrop graven under steinane i anlegget (Ahlqvist \& Shekari, 2017, s. 10-11). Lagfølgja liknar situasjonen hos det nærliggande Anlegg 10, men interessant nok er dateringa frå Anlegg 11 klart eldre.

Det er mogleg at alt av ${ }^{14} \mathrm{C}$-datert forkola organisk materiale frå dei tre steinleggingane øvst på kollen (Anlegg 12, 13 og 14) stammar frå ulike fasar av avsviing og rydding av området for beitemark. Alle desse tre steinkonstruksjonane kan i sin tur vere bygd for ritual og kultisk aktivitet så seint som i romartid, jamføre kremasjonsgrava/-deponeringa i Anlegg 14. Dette er noko som også kan gjelde for somme av dei andre ${ }^{14} \mathrm{C}$-daterte steinkonstruksjonane, for ingen av desse dateringsresultata kan sikkert knytast direkte til bygging eller bruk av anlegga. Det daterte prøvematerialet kan stamme frå eldre aktivitet på staden. Dette viser til veikskapar i prosessen med prøvetaking og ${ }^{14} \mathrm{C}$-datering i samband med Orstad-undersøkinga. Ein ville ha tent på å gjennomføre ei standardisert rutine for innsamling av prøver, slik at metodikk og tal på prøver blei tilnærma like for alle dei steinbygde anlegga. Vidare, som ein konsekvens av denne rutinen, burde det ha vore tilgjengeleg nok ressursar til å ${ }^{14} \mathrm{C}$-datere materiale frå fleire (minst 2-3 stk.) identifiserte kontekstar innan kvart utvalt anlegg. Ei slik systematisk datering opnar opp for ei langt betre forståing av formasjonsprosessane på staden, både for det enkelte anlegget og for den samla konteksten for «monumentet». Men, det er uansett ikkje til å kome frå at å ${ }^{14} \mathrm{C}$-datere slike steinkonstruksjonar på fragment av forkola frø eller tre, er ein kjeldekritisk problematisk framgangsmåte, særleg dersom hovudfokuset er på deponeringar/gravleggingar.

Det vidare arbeidet med dei jordkjemiske prøvene (jf. Hollund \& With, 2015) føregjekk ved ein kombinasjon av glødetapsanalyse og bruk av pXRF. Analysane kunne ikkje gje klare svar på om dei prøvetekne anlegga på eit tidspunkt hadde innehalde beinmateriale. Men, samstundes viste det seg at prøvene frå kremasjonsgrava/-deponeringa i Anlegg 14 heller ikkje ga distinkte utslag i høve til kontrollprøvene. Dette tyder på generelt dårlege bevaringsforhold for organisk materiale og karbonat innan undersøkingsområdet. Desse resultata kan såleis ikkje brukast til verken slå fast eller avvise at anlegga har vore brukt som graver eller andre former for deponeringar.

\section{Konklusjon og forslag}

Forvaltingsarkeologien treng å endre seg. Kompleksiteten ved og verdien av smålåtne, steinbygde «røyser» må forståast betre og respekterast høgare. Dette vil føre forvaltinga meir i line med oppfatningane innan den spesifikke forskinga på denne tematikken og såleis gje ei forskingsbasert forvalting i praksis. Artikkelen har reflektert rundt ei rekkje faktorar knytt til dispensasjonsundersøkingar av slike steinkonstruksjonar. Erfaringar frå utgravinga i 2014 på Orstad i Klepp kommune er nytta som døme på meir eller mindre vellukka grep for å forstå slike lokalitetar.

Fleire avgjerande tolkingar har kome til anten for tidleg (i planleggingsfasen) eller for seint (i etterarbeidet). Dette har resultert i informasjonstap i høve til lokalitetane sitt potensial. Den utbreidde tanken i forvaltingsarkeologien om at slike anlegg anten er ryddingsrøyser eller gravminne, er fagleg utdatert og set uheldige grenser for målsetnaden om å oppnå betre tolkingar av både enkeltstrukturar og av større kulturminnekontekstar i landskapet. Artikkelen har vist korleis metodeval og tolkingshorisont i planleggingfase og feltarbeid direkte påverka kva som var mogleg å finne og forstå på Orstad. 
Ein bør fjerne seg frå det tradisjonelle fokuset på det «okulære og insulære» (røyser forstått enkeltvis, som synlege og tydelege) og dikotomien «gravlegging eller rydding».

Erfaringane frå Orstad-undersøkinga peikar på nokre praktiske grep som hevar kvaliteten på slike utgravingar. Noko av det viktigaste er å nytte maskinkraft. Først og fremst omfattar dette flateavdekking og avtorving for både steinbygde anlegg og områda mellom og rundt dei (jf. Fig. 3 og 4). Slik metodikk gjev tidleg oversyn over heilskapen på ein lokalitet, noko som er verdfullt som grunnlag for prioriteringar av det vidare arbeidet. Det vert lettare å sjå at dei enkelte anlegga ikkje er skilde øyer av forhistorisk aktivitet, men derimot bitar av noko større, eit «monument» om ein vil. Maskinkraft er også til stor nytte seinare i undersøkingsprosessen, til å løfte bort tunge steinar og reinse opp overflater. Det er viktig å ikkje undervurdere dei førhistoriske menneska si vilje og evne til å flytte på store steinar for å skape kontekstar og kommunikasjon. Heile blokker på mange hundre kilo har blitt anten fjerna frå eller henta inn til eit område, og det er påvist groper og andre anleggsspor under slike store steinar (Karlenby et al., 2011, s. 135; Röst, 2016, s. 168).

Det kan vere krevjande å finne rett detaljnivå for demontering og dokumentasjon ved den manuelle utgravinga av steinbygde anlegg. Idealsituasjonen er å ha nok tid, pengar og kompetanse til å grave ut eit omfattande tal på slike strukturar ved hjelp av «single context»-metodikk. Erfaringane frå Orstad viser at denne framgangsmåten kan vere vanskeleg å få gjennomført dersom dei rette ressursane ikkje er tilgjengelege. Det finst alternative grep som kan prøvast ut for å kompensere for slik ressursmangel, men bruken av desse raskare og enklare metodane må alltid vurderast opp mot målet om fagleg god nok kvantitet og kvalitet på datainnsamlinga.

Vass-sålding av alle lausmasser frå steinbygde anlegg er tidkrevjande og kan opplevast som lite fruktbart i eit kost-/nytte-perspektiv. Tradisjonelt sett har ei pragmatisk løysing her vore å starte opp med slik sålding først når ein har klart å påvise funn ved hjelp av manuell utgraving. Denne trua på «graveskeia sitt auge» kan fungere ved undersøking av klare anlegg med distinkte funn, men vert for lettvint i denne samanhangen. Med tanke på det avgjerande informasjonspotensialet i små, spreidde fragment som eit kremert tåbein i Anlegg 10 på Orstad, synest systematisk vass-sålding å vere ein naudsynt pris å betale. Det er samstundes naudsynt at dei få funna ikkje blir faglege halmstrå som ein klamrar seg ukritisk til fordi dei er det einaste som finst.
Det er grenser for kor mykje truverdig tolking ein kan presse ut av ein steinkonstruksjon sine spreidde innslag av sotflekkar, leirkarskår, flintbitar og udiagnostiske brente bein - men desse grensene kan stadig flyttast, i retning av større kunnskap og mindre informasjonstap. Ein måte å gjere det på, er gjennom auka fokus på tverrvitskapeleg samarbeid. Ved Orstad-undersøkinga satsa ein aktivt på å dra nytte av naturvitskapelege analyser for å forstå og datere førhistorisk aktivitet. Dette gav varierande resultat, frå klar påvising av jordbruksaktivitet til undring over nedbrytingsprosessar. Ein annan måte er å løfte blikket frå kvart enkelt funnførande anlegg og heller leite etter mønster, både innan dette undersøkingsområdet og, i enno større grad, med liknande lokalitetar. Det finst rett og slett behov for statistiske analysar av det totale funnmaterialet.

Målsetnaden om å dokumentere grundig eit representativt utval frå ulike kategoriar av «røyser» er krevjande å få til i praksis. Korleis skal ein gå fram for å velje rett, når ulikskap er tydlegare enn mønster? For det første, så bør tolkingar og prioriteringar vere basert på utsegnskrafta til det påviste kjeldematerialet. Ein avtorva konsentrasjon av intensjonelt deponerte steinar er på dette tidspunktet i undersøkingsprosessen faktisk verken ei «ryddingsrøys» eller ei «gravrøys», det er ein steinkonstruksjon med uforløyst informasjonspotensial. Metodikk for utgraving og dokumentasjon burde veljast utifrå det som høver best til den kunnskapen ein har om undersøkingsobjektet si oppbygging og innhald, ikkje plasseringa innan eit «kulturminnehierarki», med gravminne på topp og steinrydding på botn. Ein felles standard for undersøking og dokumentasjon av steinkonstruksjonar bør såleis vere det generelle utgangspunktet i ein prosjektplan. Dersom ein av ulike årsaker vel å fråvike dette prinsippet, så er det viktig at ein har reflektert over kva dette kan medføre av informasjonstap. Denne artikkelen har vist at bruk av ulike metodar i felt har sine fordelar og ulemper. Dersom ein i prosjektplanen vel som målsetnad å totalgrave utvalde steinkonstruksjonar for å finne sjølv dei minste spor etter deponeringar og andre formasjonsprosessar, så er det truleg berre «single context»-metode kombinert med vass-sålding som gjer jobben godt nok. For prosjekt der jakta på deponeringar er tona ned, og fokus i staden hovudsakleg er på å få «god nok» informasjon om oppbygginga av eit større tal på steinkonstruksjonar, kan meir tilpassa og enklare metodar vere fruktbare. Det er truleg i den sistnemnde prosjektvarianten at dei største utfordringane kan oppstå når planen møter feltsituasjonen. For kva gjer ein dersom «godt nok»-steinkonstruksjonane brått 
viser seg å innehalde meir enn venta av funnmateriale og strukturdetaljar - held ein seg til den opprinnelege planen, eller justerer ein innsatsen etter beste evne til den nyvunne kunnskapen om undersøkingsobjektet si oppbygging og innhald, som eg har tala varmt for?

Eksistensen av stor variasjon i materiale tyder ikkje at alt er «kaos» og at slike anlegg generelt sett ikkje lét seg tolke. Det er lite hjelp i å gå frå ein forenkla dikotomi («gravrøys» vs. «ryddingsrøys») til eit relativistisk anarki der alle slike steinsamlingar kan vere alt eller ingenting. «Røysene» er intensjonelt skapte, basert på normer for innhald og utforming: «Utgångspunkten måste vara att det vi ser är (åtminstone delvis) spåren efter medvetna val och intentioner» (Röst, 2016, s. 226). Utfordringa ligg $i$ at desse normene er delvis ukjende, og at dei har endra seg over tid - fleire av bitane i puslespelet er borte, og motivet har skifta fleire gongar. Tida er uansett komen for at eit underkommunisert og delvis misforstått kjeldemateriale knytt til «vanskelege» steinkonstruksjonar bør få den handsaminga ved forvaltingsundersøkingar som den arkeologifaglege forskinga over fleire tiår har vist at det fortener.

\section{Summary}

There is a need to improve how archaeological investigations of sites with "hard-to-grasp", inconspicuous prehistoric stone-built structures, often labelled "cairns", are conducted in Norway. This article has demonstrated that there is, in some cases, clearly a lack of integration of updated archaeological research results on this topic into the everyday Cultural Heritage Management processes. These kinds of sites clearly have the potential to yield more and different types of information about the past than previously assumed.

The article presents a short introduction of some of the main results from Scandinavian archaeological research on such stone constructions. One key aspect here is the rejection, as an oversimplification, of the prevalent notion that these "cairns" are either built as containers for, and markers of, burials or as mere heaps for clearance. They should instead be recognized as fragments containing other fragments; stone assemblages with deposits that are the remains of several construction and deconstruction events, where the intentional fragmentation of human remains, objects and the structures themselves may have been as important in the past as the ritual processes of building up clear, visible contexts of stones, bones and other materials. Traditionally applied criteria for the categorization of "graves" and "non-graves", such as size, symmetry and placement in the landscape have been proven insufficient, and even the applicability of the "burial" concept is challenged by evidence of the deposit, and sometimes most likely the re-deposit, of only a tiny percentage of a cremated individual. These bones could have been used in rituals focused on more general processes of creation, degradation and transformation within the larger context of several stone constructions forming a "monument" in the Bronze Age and Early Iron Age landscape.
The presentation of the Orstad case study gives a number of recent examples, from a development-led excavation, of how the lack of adequate consideration of research on the complexities of these localities can cause unnecessary information loss in the fieldwork phase. A better way forward for planning and executing such archaeological investigations is suggested. The importance of using machinery for both mechanical stripping of turf and topsoil from both the stone constructions and the wider area surrounding them, and for facilitating further stone removal later on in the excavation process is emphasized. The author also advocates the use of water sieving for finds retrieval, discusses pros and cons with single context recording and shows how crucial it is for such complex sites to have a well prepared and stringent sampling strategy. Decisions on prioritizations and categorizations should be based on specific information gained from actual investigation of the site, not on old-fashioned general preconceptions about such stone constructions' usage and value in prehistory. Only through systematic and consistent methods for excavation and documentation can we achieve a comparably trustworthy data set for further research.

This article, with its evaluation of actual results gained from the excavation and documentation methods applied at the Orstad site, informed by and contrasted with Scandinavian research findings, is to be regarded as a starting point for further discussions on the intricate and fascinating topic of those old heaps of assembled stones.

\section{Litteratur}

Ahlqvist, J. \& Shekari, S. (2017). Naturvetenskapliga analyser av gravrösen, rösen och anläggningar Id. 157479 och 157480 i Orstad, gnr. 9, Klepp kommune, Rogaland. Oppdragsrapport 2015/10. Arkeologisk museum, Universitetet i Stavanger.

Arcini, C. (2007). Elden utplånar inte allt: Brandgravar och bålplatser vid Gualöv. I M. Artursson (Red.), Vägar till Vetland: en bronsåldersbygd i nordöstra Skåne 2300-500 f.Kr. Stockholm: Riksantikvarieämbetets förlag. Artelius, T. (2000). Bortglömda föreställningar. Begravningsritual och begravningsplats $i$ halländsk yngre järnålder. Riksantikvarieämbetet Arkeologiska Undersökningar Skrifter 36 Gotarc Series B. Gothenburg Archaeological Theses 15. (Doktoravhandling.) Riksantikvarieämbetet, Stockholm, og Göteborgs universitet Institutionen för arkeologi.

Arkeologisk museum, UiS (2013). Prosjektplan og budsjett for arkeologisk undersøking på Orstad Id. 157479 og $157480 \mathrm{i}$ 2014. Utarbeidd for og godkjent av Riksantikvaren (RA).

Bjørdal, E. \& Rødsdalen, S. S. (2017). Arkeologisk undersøkelse av røysfelt frå bronse - og jernalder på Orstad gnr. 9, bnr. 8 og 15, Klepp k., Rogaland. Oppdragsrapport 2015/10. Arkeologisk museum, Universitetet i Stavanger.

Bortheim, K. \& Dahl, B. I. (2014). Arkeologisk undersøkelse av røysfelt fra E.BRA og bosettingsspor fra E.FØRROM $i$ Tjemslandsmarka: Tjemsland Nordre, gnr. 53, bnr. $1 \mathrm{og}$ 68, Hå kommune, Rogaland. Oppdragsrapport 2014/2. Arkeologisk museum, Universitetet i Stavanger.

Denham, S. D. (2015). Burnt bones recovered from Orstad, Klepp k. Internt notat om osteologisk analyse av beinmaterialet frå den arkeologiske undersøkinga på Orstad Id. 157479 og 157480 i 2014. I S. S. Rødsdalen \& E. Bjørdal, 
Arkeologisk undersøkelse av røysfelt frå bronse- og jernalder på Orstad gnr. 9, bnr. 8 og 15, Klepp k., Rogaland. Arkeologisk museum, Universitetet i Stavanger.

Dommasnes, L. H. (1997). Tradisjon og handling i førkristen vestnorsk gravskikk. Undersøkelser på et gravfelt på Vereide $i$ Gloppen, Sogn og Fjordane. Arkeologiske Rapporter 21, Bergen: Arkeologisk institutt, Universitetet i Bergen.

Forsman, C. \& Victor, H. (2007). Sommaränge Skog: begravningar, ritualer och bebyggelse från senneolitikum, bronsålder och folkvandringstid. Rapport del 1: De förhistoriska lämningarna vid Sommaränge skog, RAÄ 211, Viksta sn, Uppland. Med bidrag av Markus Andersson, Kristina Anfält, Tony Engström, Per Falkenström, Anne Ingvarsson-Sundström, Helena Knutsson, Emma Sjöling, Jhonny Thérus, Annika Westerholm, Emelie Schmidt Wikborg \& Jonas Wikborg. (Societas Archaeologica Upsaliensis Skrifter 18). Uppsala: Societas Archaeologica Upsaliensis.

Hansson, M. (2008). En gammal grävning, ett kulthus och ett antikvariskt problem. I J. Goldhahn (Red.), Gropar och monument. En vänbok til Dag Widhol, s. 147-169. Kalmar: Högskolan i Kalmar.

Hemdorff, O. (1987). Langhus fra slutten av bronsealderen - funnet på Håbakken, Klepp. Frá haug ok heiðni 3, $228-235$.

Hemdorff, O. \& Sageidet, B. (1997). En hveteåker fra eldre bronsealder på Orstad, Klepp - en spesialisert jordbruksboplass? Frá haug ok heiðni 1, 13-15.

Holck, P. (1996). Cremated bones: a medical-anthropological study of an archaeological material on cremation burials. 2nd rev. edition. Vol. nr. 1b. (1. utg.: Avhandling (doktorgrad) - Universitetet i Oslo, 1987). Oslo: Anatomical Institute, University of Oslo.

Hollund, H. I. \& With, R. (2015). Jordkjemiske undersøkelser av røysfeltet på Orstad, Klepp k.: Gård: Orstad, Gårdsnr/bruksnr: 9/15 og 34, Kommune: Klepp: Stavanger. Oppdragsrapport 2015/2. Arkeologisk museum, Universitetet i Stavanger.

Häggström, L. (2007). Öggestorp och Rogberga: vägar till Smålands förhistoria. Jönköping: Jönköpings läns museum.

Kaliff, A. (1997). Grav och kultplats: eskatologiska föreställningar under yngre bronsålder och äldre järnålder $i$ Östergötland. Aun (24). (Doktorgradsavhandling.) Uppsala: Department of Archaeology, Uppsala University.

Kaliff, A. (2009). Tolkning eller analytiskt redskap? Om terminologins betydelse vid tolkning av rituella lämningar. I I. -M. Back-Danielsson, I. Gustin, A. Larsson, N. Myrberg \& S. Thedéen (Red.), Döda personers sällskap: gravmaterialens identiteter och kulturella uttryck. Stockholm Studies in Archaeology (47), s. 19-34. Stockholm: Institutionen för arkeologi och antikens kultur, Stockholms universitet.

Karlenby, L., Kaliff, A., Goldhahn, J. \& Thedéen, S. (2011). Stenbärarna: Kult och rituell praktik $i$ skandinavisk bronsålder. Uppsala: Uppsala universitet.
Lillehammer, G. (1996). Død og grav: gravskikk på Kvassheimfeltet, Hå i Rogaland, SV Norge. Death and grave: burial rituals of the Kvassheim cemetery, Hå in Rogaland, SW Norway. AmS-Skrifter 13, Arkeologisk museum i Stavanger.

Lönn, M., Apel, J. \& Brorsson, T. (2014). Kultplatsen på Stora Holm. UV Rapport 45/2014, Riksantikvarieämbetet, UV Väst, Mölndal.

Oestigaard, T. (1999). Cremations as transformations: When the dual cultural hypothesis was cremated and carried away in urns. European Journal of Archaeology, 2 (3), 345-364.

Petersson, M. (Red.).(2015). Farstorp - ett röjningsröseområde i långtidsperspektiv. Rapport 2015:116, Arkeologiska uppdragsvirksomheten, Statens historiska museer, Linköping.

Rødsrud, C. (2004). Gravfelt fra førromersk jernalder og overgangen til romertid. I L. Melheim, K. Oma \& L. Hedeager (Red.), Mellom himmel og jord. Foredrag fra et seminar om religionsarkeologi, Isegran 31. januar-2. februar 2002. s. 274 -291. Oslo arkeologiske serie 2, IAKK, Universitetet i Oslo.

Röst, A. (2014). Tydlig gravgömma saknas?:

Stenkonstruktioner och depositioner av kremerade ben på två gravfältslokaler från yngre bronsålder i Södermanland. I M. Ljunge \& A. Röst (Red.), I skuggan av solen. Nye perspektiv på bronsåldersarkeologier och bronsålderns arkeologiska källmaterial, s. 117-147. Stockholm: Institutionen för arkeologi och antikens kultur, Stockholms universitet.

Röst, A. (2016). Fragmenterade platser, ting och människor: Stenkonstruktioner och depositioner på två gravfältslokaler i Södermanland ca. 1000-300 f.Kr. Stone constructions and deposits in two burial grounds in Södermanland, ca. 1000-300 BC. Stockholm Studies in Archaeology (71) (Doktorgradsavhandling.) Stockholm: Institutionen för arkeologi och antikens kultur, Stockholms universitet.

Sjölin, M. (2015). Komplexa stenrösen och stensättingar. I M. Petersson (Red.), Farstorp - ett röjningsröseområde i långtidsperspektiv, s. 56-88. Rapport 116/2015, Arkeologiska uppdragsvirksomheten, Statens historiska museer, Linköping.

Sjöling, E. (2007). Bränt, begravt och nedbrutet. Fältarkeologiska studier av brända ben. I M. Notelid (Red.), Att nå den andra sidan: om begravning och ritual i Uppland. Uppsala: Riksantikvarieämbetet, UV GAL, Societas archaeologica Upsaliensis, Upplandsmuseet.

Vivås, A. (2012). Kulturhistoriske registreringer. Reguleringsplan - områdeplan for Orstad. Orstad gnr. 9, bnr. Fleire, Klepp k. Rapport 43/2012. Rogaland fylkeskommune, Regionalutviklingsavdelingen, Kulturseksjonen.

Wangen, V. (2009). Gravfeltet på Gunnarstorp i Sarpsborg, Østfold: et monument over dødsriter og kultutøvelse i yngre bronsealder og eldste jernalder. Norske Oldfunn XXVII. Oslo: Kulturhistorisk museum, Universitetet i Oslo. 